\title{
Right Atrium
}

National Cancer Institute

\section{Source}

National Cancer Institute. Right Atrium. NCI Thesaurus. Code C12868.

One of the four chambers of the heart, which is located immediately superior to the right ventricle, and which receives deoxyg enated venous blood from the systemic circulation. 